\title{
The Cultivation of Aesthetic Taste in General Education Classrooms: A Case Study of the Course of Classical Western Literary Theory
}

\author{
Yanqiu Li ${ }^{1,2}$ \\ 1. School of Foreign Studies \\ East China University of Political Science and Law \\ Shanghai, China \\ 2. School of Foreign Languages \\ Shanghai Jiaotong University \\ Shanghai, China \\ jinyu0130@qq.com
}

\begin{abstract}
To justify the place of the course in the curriculum for first-year college students in general education classrooms, two major aspects including general education and aesthetic education are considered. The target audience is the freshmen in East China University of Political Science and Law who haven't started their professional education in a profound, systematic and comprehensive way. Firstly, the course can be viewed as an integral part of both general education and aesthetic education. It can contribute greatly to the formation of character, the realization of human potential in general. Secondly, it can enhance the aesthetic awareness and aesthetic judgment in specific. Self-cultivation, self-identification and self-realization can be the key factors which make the course an integral part of general education while aesthetic sensitivity, aesthetic taste and aesthetic judgment are the main aspects which the course is designed to improve and cultivate so as to achieve human liberty and morality from an aesthetic perspective. Therefore, the course is justified in the cultivation of aesthetic taste in general education classrooms.
\end{abstract}

Keywords-general education; aesthetic education; classical western literary theory; function of literature

\section{INTRODUCTION}

This paper aims at justifying the course of classical western literary theory in the curriculum for first-year college students in general education classrooms. The target audience is the freshmen in East China University of Political Science and Law who haven't started their professional education in a profound, systematic and comprehensive way. There are two aspects to justify it, as the course itself can be viewed as an integral part of both general education and aesthetic education. It can contribute greatly to the formation of character, the realization of human potential in general as well as enhance the aesthetic awareness and aesthetic judgment in specific. Selfcultivation, self-identification and self-realization can be the key factors which make the course an integral part of general education while aesthetic sensitivity, aesthetic taste and aesthetic judgment are the main aspects which the course is designed to improve and cultivate so as to achieve human liberty and morality from an aesthetic perspective.

\section{GENERAL EDUCATION}

\section{A. General Education Classroom}

Firstly, the course can be congenial to what general education is designed for. General education can be traced back to liberal arts education which is designed for self-cultivation, self-identification and self-realization [1]. Liberal arts education is more like what we call for big learning in opposition to small learning which is designed to implant a sort of practical skill, technique or art. It is quite difficult to evaluate whether courses conducted to achieve self-cultivation, self-identification and self-realization are effective or not in the short term, as self-cultivation, self-identification and selfrealization are impossible to be evaluated by a set of fixed principles and standards. However, there's no denying that it is the core or driving force behind education, particularly institutions of higher education or embodiment of big learning. The process of a person's growth and maturity can be achieved by cultivating personal taste and interest, by identifying self and personal ethics, by realizing personal potential and talents, all an attempt to make the wholeness of a man. It is easier to testify the success of professional education or small learning, as it's only served as a single and achievable indicator of a certain kind of competence and ability. General education aims high and focuses on what makes a whole man, civilly, culturally, and morally. It is likely that practical problems may not be solved by general education, but nothing can be really established and achieved without general education at its core. Even though general education is different from professional education in its content, purpose and function, they are not and should not be exclusive and contradictory [2]. Conversely, only by combining the two modes of education can higher education fulfill its function. General education is likened to a whetstone which itself doesn't cut but sharpens the knife undoubtedly. As professional education is said to be more utilitarian and 
practical, only general education can set the practicability of professional education in its right direction and just place.

\section{B. The Course of Classical Western Literary Theory}

To be specific, the course is titled as classical western literary theory. The target audience of the course is the freshmen in East China University of Political Science and Law who haven't started their professional education in a profound, systematic and comprehensive way. It is based on and derived from the classical texts dating from ancient Greek times to the nineteenth century. The classical texts that the students are required to read are classified chronologically as follows: classical heritage of ancient Greek and Roman times, Renaissance and Neo-Classicism, eighteenth to nineteenth century. The division of time is easier but not accurate and enlightening. The course could be more effectively conducted if it's topic focused. There are several ways to find a selection of topic or fundamentals issues to elaborate on. For example, the essences of literature or poetry in antiquity, the function of literature, the role of poetry, and the justification of it are top on the agenda. It's noticeable this period can be typical or even determining in its impact. During that time, the world of literature and art is still oriented towards 3 major pairs of relations: the relationship between the text and the universe, the relationship between the text and the writer, and the relationship between the text and the reader, when the mimetic theory, pragmatic theory and expressive theory took shape, began to dominate and further reinforced. Chronologically speaking, it's the longest existing heritage that the western world has to offer which is also the source and origin of all western civilization to some extent. It can enable the students to be equipped with a broader view, huge vision, historic awareness, cultural relevance and critical mode of thinking. As general education plays a leading role in self-cultivation, selfidentification and self-realization, the course can meet the requirements of general education in moral ideal, cultural ideal and civil ideal from the perspective of western classical literary theories.

\section{A Case in Point}

Next comes a very good case in point to demonstrate the applicability and practicality of such a course. The very first text students would read is Book X in Plato's Republic. Even though, it's mainly about Plato's criticism of the poets and their poetry as well as his decision to banish them from his republic, it could be viewed as a miniature of the physical world or a reflective representation in a fictional world. In order to bring justice back to a city state, Plato's criticism of poetry and poets indicates a solution to the urgent problem. Though it remains controversially biased in terms of his criticism, the impact of poetry and poets can never be highlighted. Even Plato himself cannot resist the temptation of reading Homer, claiming to be an admirer of Homer, his attitude towards poets and poetry cannot be simply explained without reference to the historical, cultural, philosophical and political context. This boils down to the fact that Plato's accusation of poets and poetry itself is an everlasting proof of the irresistibility and contagion of poetry, or literature and art in modern sense. Even though he is mainly concerned with what makes a just state, what kind of poetry is just and what kind of poets can be justified always lingered on his mind. As the poetry closely affected the soul of people, either the rational or irrational part, poetry is to blame in the first place. If the rational part of the soul is in control, there is justice in poetry just like the hymns to the gods and heroes, which fostered the strong-will and reason of the philosopher kings, high spirits of the defending military, enhanced the virtues of both men and women in general, and formed the humors of human beings. If the irrational part of the soul takes over, the poetry can disrupt justice in a city state on a large scale, corrupt the body and soul of its readers, lead to the disorder and destruction of a city state and its people. Plato expelled artistic representation because he associated it with an excessive freedom and disorder; he believed that art encourages citizens to compete over roles and responsibilities [3]. Therefore, not only literature but also arts are in crisis. In antiquity, literary criticism is for Plato the unreluctant enforcer of ethical principles, and it ensures that literature provides only positive models of behavior [4]. Poetry and poets are to blame with the mixed and bewildering function of morality and criticism. Plato in a way initiated a debate over the domain of literature, criticism and ethics. He is always at the center stage for any later theorists, critics, philosophers to apprehend, emulate, and challenge. This sort of debate is closely linked with a firm belief in moral ideal, cultural ideal and civil ideals. $\mathrm{He}$ is symbolically considered as the first one to set up a tradition of literary criticism. Criticism itself deals with moral issues and social function of literature.

Thus, in accordance with the integral part of general education, questions and debates like these can only be traced back to the very early texts that students are required to read in the course. Students are forced to reexamine and explore the existing ways of criticism, about the process and interplay of criticism, literature, and ethics in general. If ethical awareness and critical perspective can be properly and justly reconciled, readers of the classical texts, or students of the course can be inspired to tackle the issue by relying on the fruits of classical writers. Therefore, the course is justified as an integral part of general education.

\section{Aesthetic Education}

\section{A. Aesthetic Perspective}

In addition to the controversially inspirational approach of ethics and criticism, the justification of the course can also be done from the aesthetic perspective. As an old Chinese saying goes, the love of beauty is common to all. It's not only a Chinese preference but also a universal belief in the love of beauty and improvement of aesthetic taste. People without the aesthetic judgment are incurably bored and merciless and eventually unable to find the meaning of life. Life for them means only to survive rather than to live. German philosopher Alexander Baumgarten applied the term "aesthetica" to the arts, of which the aesthetic end is the perfection of sensuous cognition, as such; this is beauty [5]. Since then, a systematic study of all the fine arts, as well as the nature of beauty in any object, whether natural or artificial, known as aesthetics, came into being to address some of the fundamental issues. Aesthetics, in Hegel's term, known as the philosophy of fine arts, is based on the human senses and designed to improve the 
acquisition of sensual knowledge. Though the biological function of human is basically the same, human cognition needs to be advanced and guided. Only those who judge with the proper function of the senses can be able to take great delight in the experience, or aesthetic experience.

\section{B. Fundamental Issues}

To be specific, there are some fundamental issues to be addressed in this course from the perspective of western literary theories, such as what beauty is, whether people are sensitive to beauty in general, whether people can be cultivated to be enthusiastic and creative, whether aesthetic awareness can be enhanced or not. Students may wonder whether they are able to display advanced aesthetic judgment and discern new perspectives by relying on the classical or old texts. However, that's exactly what the course aims at. It's designed to give old message more resonance in today's context. As all the texts are classical texts or known as the recognized heritage of the west. By knowing the West can we reflect upon contemporary East, by identifying the roots can we absorb the present fruits, by reviewing the old can we create. That's the basic need for freshmen to take such an optional course to bring new meaning to their understanding of present Oriental and Western world. It's hard to verify where the course can improve their sense of judgment in general. But it offers time-proof perspectives about how a certain notion of beauty took shape how a certain mode of thinking had its roots in those writing of classicists. For instance, Edmund Burke believed that taste, in its most general acceptation, is not a simple idea, but is partly made up of a perception of the primary pleasures of sense, of the secondary pleasures of the imagination, and of the conclusions of the reasoning faculty, concerning the various relations of these, and concerning the human passions, manners, and actions. All this is requisite to form taste, and the groundwork of all these is the same in the human mind; for as the senses are the great originals of all our ideas, and consequently of all our pleasures, if they are not uncertain and arbitrary, the whole groundwork of taste is common to all, and therefore there is a sufficient foundation for a conclusive reasoning on these matters [6]. Burke's optimistic view on the common interplay of sense, imagination and reasoning convinced us of the belief in human intellect to improve taste and urged us the desperate need for aesthetic education. Since it's common to all that beauty can be quite delightful and pleasing, what constitutes the standards of taste in term of aesthetic experience, how to judge the delights or terrors of the aesthetic experience, how to downplay the misleading judgmental assumptions, need to be taken seriously and addressed properly. Burke's inquiry offers inquisitive, tentative solutions. In his book, judgment, knowledge acquisition, steady focus and consistent practice are key aspects of taste improvement. Furthermore, Immanuel Kant believed that taste is the faculty of estimating an object or a mode of representation by means of a delight or aversion apart from any interest [7]. Aesthetic experience, with a purposeless purpose, appeals to us all with a pure and simple delight, regardless of utility or morality. Such a purposeless purpose can better compel us to put aside personal preference, personal interests and focus on the experience itself. It is so disinterested that it is free from bondage and can be viewed as a symbol of moral liberty for human beings. Thus, in the world of literature of art, the moral liberty of the readers is not only the agreeable product of aesthetic experience but also the sweet stimuli to engage in such an attempt.

\section{The Function of Literature}

Contrary to the interplay of ethics and criticism, aesthetic approach can instill readers with a self-conscious attempt to seek delight, cultivate taste and pursue beauty. For instance, students are encouraged to reflect on the Kantian remark on art as a symbol of morality and Schiller's follow-up personified version of art as daughter of freedom [8]. The function of literature is elevated to the height of morality from the sensual cognition to the eventual human ideal of freedom. Freedom or human liberty, as an idea as well as a solution, can inspire humans to take actions and make common efforts with a firm belief. The nature of human can provide the likely conditions of ethical freedom and action so that a consensus can be reached that people share an equal capacity for experiences. Universal experience guarantees the coexistence between art and morality. Classical figures such as Plato and Horace pinpointed the educational and pleasing function of poetry. They told us what it was but didn't show us why it was. We kept on thinking about what's behind the entertaining and education function and got the answer: human nature. It is human nature to seek happiness, to acquire knowledge, to be indulged in pure, simple and even free pursuit of happiness and beauty. With those classical figures in the background, Burke informed us of the common ground to improve taste and the possibility of achieving such a goal. Kant convinced us of the likelihood of similar human faculty of aesthetical judgment, which is equality-oriented. Poetry or literature should be justified in the improvement of man, morally, aesthetically and holistically. The secrets of human nature are gradually revealed as several classicists and neo-classicists worked together to discover the liberty of human soul in its eventual and constant pursuit. Therefore, it's inspirational enough for contemporary readers to find the answers and solutions in the classical texts.

\section{In the Context of Contemporary China}

The ultimate goal of fulfilling human liberty with the help of aesthetic experience resonates with the original task of general education, as general education abounds in the libertydriven experiences and guidance. Liberal arts education can be viewed as the precedent of general education despite of its difference, the linking tie should be the cultivation of the soul in its relation to nature, universe and mankind. The western text in the eyes of Chinese readers is reminiscent of the universal liberty or freedom of the human soul, either west or east. As self-cultivation, self-identification and realization is never a wholly western tradition, the liberal tradition in China is also worth mentioning. As De Bary stated that the tradition of liberal education in China was deeply rooted in the moral ideal, cultural ideal and civil ideals [9], the reading of the western classical literary theories can offer students the chance to relate ancient western wisdom to contemporary Chinese context, to integrate rich Chinese tradition with western heritage, to reflect with their perspective and sense of judgment when the West meets the East, and to look beyond the boundaries and think as an intellectual, rational, emotional and 
ethical thinking being. The inclusiveness of the course can foster a critical reflection on the western intellectual tradition as well as Chinese cultural traditions. A very good case in point is the reading of Horace's The Art of Poetry and Edmund Burke's A Philosophical Inquiry into the Origin of Our Ideas of the Sublime and Beautiful. In general education classroom of classical western literary theory, it is not rare that students kept on pondering over the validity, efficiency and value of the classical text in view of its distance from present conditions. However, their doubt and suspicion can be removed quickly and suddenly when they encountered with the odd and wired image of a mermaid on the beginning pages of Horace's The Art of Poetry. In their pursuit of an answer, traditional perspective tended to focus on the issue of decorum to explain such an absurdity. Burke's discussion about the standards of aesthetic taste offers new perspectives for students. They are reassured of the possibility of a relatively fixed standard of taste to justify the rules of decorum. The standards of taste can only be fixed or established with the precondition that the human soul could be free or is in constant pursuit of liberty. On the surface, students are solving the problems of the British empiricists but indeed they are discovering a universal rule to reflect on the intellectual and aesthetic response to the object, the universal subjectivity reflected in the object of literature and art world.

\section{CONCLUSION}

The cultivation of an aesthetic taste for students in general education classrooms with the course of western classical literary theories as a case study can be justified as it best embodies the core values of general education and aesthetic education. Plato established the tradition of literary criticism to question the nature of poetry and the function of poetry. Horace elucidated the educational and entertaining function in defense of poetry. Burke's tentative discussion about the taste, judgment, imagination helped us to see through the formal accusation and defense and pinpointed the possibility of a fixed standard of taste. Kant's groundbreaking proposal of the disinterested aesthetic experience opened our eyes to the hidden secrets of the accusation and defense. Above all, the human liberty, the critical approach, the literature and art, are only indicators of human nature. While general education placed great emphasis on the nature of human beings: selfcultivation, self-identification and self-realization, aesthetic education further enhanced the pursuit of ethical liberty and human freedom. Both encourage readers to put universal principles first and individual interests second, integrate selfcultivation and self-identification with universal interests and subjectivity.

In China, a broader view, a comparative outlook on the human cultural heritage, and a universal aesthetic experience are viewed as indispensable qualities for self-growth and maturity. The course of the classical western literary theory better embodies the universal interests and self-realization, self- cultivation and self-identification as well as impacts students' response as a liberal thinking human being. In a highly horizontal economy where professional education is gaining weight with its profitability, freshmen need to be implanted with an aesthetic judgment and sensitivity in order to lay a solid foundation for their character development and spiritual training and perfection. Therefore, the course is justified from the perspective of general education and aesthetic education.

\section{ACKNOWLEDGMENT}

First, I would like to express my deepest gratitude to my supervisor, Prof. Weiwen He, a respectable, responsible and resourceful scholar who has provided me with valuable guidance in every stage of composing the essay. Without her enlightening instruction, impressive patience and kindness, I could not have completed the paper. Her keen and vigorous academic observation and insight enlighten me not only in my composure but also in my future academic study and research.

Second, I shall extend my thanks to my colleagues who have helped me to develop the fundamental and essential academic interest.

Last, I'd like to thank all my friends and family for their support and understanding.

\section{REFERENCES}

[1] Tsung Chi, "Origin, change and development of American higher education: from a perspective of liberal arts education,” in Journal of Northwestern Polytechnical University of China, 2019. p.65. (In Chinese)

[2] Guping Zhou \& Li Zhang, "General education in Chinese institutions of higher learning: retrospect and prospects,” in Educational Research, 2019, Vol. 3, pp. 65-73. (In Chinese)

[3] Tobin Siebers, The Ethics of Criticism, New York: Cornell University, 1988, p. 26.

[4] Tobin Siebers, The Ethics of Criticism, New York: Cornell University, 1988, p. 18.

[5] M. H. Abrams \& Geoffrey Galt Harpham, A Glossary of Literary Terms, Beijing: Beijing University Press, 2014, p.8.

[6] Edmund Burke, "A philosophical inquiry into the origin of our ideas of the sublime and beautiful," in Selected Readings in Classical Western Critical Theory, Beijing: Foreign Language Teaching and Research Press, 2006, p.273.

[7] Immanuel Kant, qtd in Tobin Siebers, The Ethics of Criticism, New York: Cornell University, 1988, p. 24.

[8] Tobin Siebers, The Ethics of Criticism, New York: Cornell University, 1988, p. 28.

[9] William Theodore de Bary, The Liberal Tradition in China, Beijing: Zhong Hua Book Company, 2016, pp.8-9. (In Chinese) 